\title{
Dental caries and treatment needs among indigenous people of the Potiguara Indian reservation in Brazil
}

\author{
Fábio Correia Sampaio, ${ }^{1}$ Cláudia Helena Soares de Morais Freitas, ${ }^{1}$ \\ Matilde Barbosa de Farias Cabral, ${ }^{2}$ and \\ Ana Thereza de Azevedo Britto Machado ${ }^{3}$
}

Suggested citation Sampaio FC, Freitas CHSM, Cabral MBF, Machado ATAB. Dental caries and treatment needs among indigenous people of the Potiguara Indian reservation in Brazil. Rev Panam Salud Publica. 2010;27(4):246-51.

\begin{abstract}
Objective. The aim of this study was to assess the caries prevalence and treatment needs of Brazilian indigenous residents on an Indian reservation.

Methods. This cross-sectional study comprised 1461 individuals of ages 18-36 months and $5,12,15-19,35-44$, and 65-74 years living in the Potiguara Indian villages of Brazil. Decayed, missing, or filled permanent teeth (DMFT) and deciduous teeth (dmft) were determined by calibrated examiners using the methodology recommended by the World Health Organization. Treatment needs were assessed with the guidelines of the 2003 Brazilian Oral Health Survey.

Results. Means \pm standard deviations (SD) for dmft of 18-to 36-month-old and 5-year-old children were $2.5 \pm 3.7$ and $5.8 \pm 4.3$, respectively. For the age groups $12,15-19,35-44$, and $65-74$ years, mean $\pm S D$ values of DMFT were $3.6 \pm 3.1,7.1 \pm 4.9,16.4 \pm 7.5$, and $22.8 \pm$ 8.6. The mean $\pm S D$ number of deciduous teeth requiring treatment varied from $2.4 \pm 3.5$ to $5.0 \pm 4.0$ in the 18- to 36-month and 5-year-old age groups, respectively. Among adolescents and adults, it was observed that on average at least three permanent teeth required dental treatment such as fillings, crowns, endodontic treatment, and extractions.

Conclusions. High prevalence of caries and many teeth needing treatment were observed in all age groups of the Potiguara Indians.
\end{abstract}

Key words Dental caries; DMF index; dental health surveys; dental health services; indigenous population; Brazil.

Data on oral health conditions among South American indigenous people is scarce. Until the 1970s, the few reports

\footnotetext{
Departamento de Clínica e Odontologia Social, Universidade Federal da Paraíba, João Pessoa, Brasil. Send correspondence to: Fábio Correia Sampaio, Departamento de Clínica e Odontologia Social, Universidade Federal da Paraíba, Centro de Ciências da Saúde, Campus I, João Pessoa, Brasil; e-mail: fabio.sampa@uol.com.br

${ }^{2}$ Fundação Nacional de Saúde, João Pessoa, Brasil.

${ }^{3}$ Secretaria de Saúde do Estado da Paraíba, João Pessoa, Brasil.
}

available indicated that caries prevalence among Brazilian and Venezuelan Indians was lower than in the urban population (1-4). Recently, some reports observed that processed foodstuffs, such as white sugar and soft drinks, have been incorporated into the regular diet of many Brazilian Indians (5). As a result of their changing dietary habits, an increase in the caries experience is expected for many Brazilian indigenous groups. Recent data from indigenous people living in rather remote areas indicate that they present a higher caries burden than those in urban areas of the country, where improvements in oral health are taking place (6). The high caries prevalence might be a strong trend in several Indian reservations of Brazil, and this situation might be related to the level of contact with nonindigenous groups. Certainly, cultural and geographic characteristics of each particular indigenous community may dictate the strength of this process $(7,8)$. 
Since 1999, the Brazilian Indigenous Health Care system has been centrally coordinated by the National Health Foundation (FUNASA). In order to provide more information on indigenous oral health status, FUNASA had stimulated the development of epidemiologic surveys on many Brazilian indigenous reservations. In 2001, the Special Indigenous Health District in Paraíba, a northeastern state of Brazil, carried out a preliminary epidemiologic survey on the Potiguara Indian reservation aiming to implement an oral health program. These preliminary data showed a very high number of extracted teeth among all age groups. Hence, it seems that oral health promotion was a neglected strategy in that population.

So far, there is no updated information about the caries experience in this population. Therefore, the aim of this study was to assess the caries prevalence and treatment needs related to dental caries of the Brazilian indigenous residents from the Potiguara Indian reservation.

\section{MATERIALS AND METHODS}

\section{Area of study}

The Potiguara (also known as Potyguara) are a nation of indigenous people living on a reservation area located in the Northeast Region, Brazil. The population is estimated at 8000 permanent inhabitants distributed in 26 villages of three municipalities (Marcação, Baía da Traição, and Rio Tinto) in the state of Paraíba (9).

The villages of the reservation lie on the northern Atlantic coastal area of Paraíba, where many rivers support fishing and local agriculture (corn, beans, rice, cassava) (10). The local temperature (mean annual values around $28^{\circ} \mathrm{C}$ ) is favorable for tropical fruits, which are frequently consumed. The Potiguara Indians have been subjected to a strong acculturation process and they have daily direct contact with citizens from the neighboring cities. In Baía da Traição, the most populated urban area near the reservation, water fluoridation is available but the water pipes do not reach the Potiguara reservation area. All residents of the Potiguara Indian reservation drink water with a very low fluoride concentration (11).

\section{Ethical issues}

Following Brazilian regulations, the study protocol was approved by the institutional ethical committee at the Universidade Federal da Paraíba. As indigenous people are the subject of this research, the protocol was also submitted to the Potiguara Indigenous District in Paraíba and the National Commission of Research Ethics of the Brazilian National Health Committee for approval (protocol number 12309/1700-05).

All subjects taking part in this research signed an informed consent document. Local leaders and parents signed for children and schoolchildren selected to participate in the study.

\section{Subjects and data collection}

For this cross-sectional study, the sampling procedures and the age groups were the same as those established by the 2003 Brazilian Oral Health Survey (12): 18-36 months and 5, 12, 15-19, $35-44$, and $65-74$ years of age. Also following the guidelines of the national survey, the 26 Indian villages were classified as rural areas and 12 of them were selected by using a systematic sampling procedure that took into account the population distribution. The villages selected in the municipalities were distributed as follows: Marcação $(n=2)$, Baía da Traição $(n=5)$, and Rio Tinto $(n=5)$. All houses within a radius of $500 \mathrm{~m}$ from the center of the selected village were visited. A minimal required sample size of 1138 individuals was calculated based on the reference population for each age group. For sampling, a $z$ value of 1.96 was applied to provide $5 \%$ significance. Furthermore, a 25\% increase was included, aiming to compensate for possible refusals, and resulted in a minimal target number of 1425 individuals (13). Finally, the sample of examined subjects was 1461 individuals because of the unexpected additional number of subjects in the houses located in the 500-m area established in some villages.

Before the epidemiologic survey, calibration exercises comprising practical and theoretical activities were carried out by dentists $(n=3)$. After 20 hours of training with volunteers belonging to the same age groups, interexaminer reliability was assessed and $90 \%$ agreement was reached. After training sessions, the kappa values for dental caries and treatment needs scores were higher than 0.89 .

The international standards given by the World Health Organization were used to perform the epidemiologic survey (14). The decayed, missing, or filled permanent teeth (DMFT) and deciduous teeth $(\mathrm{dmft})$ were assessed under indirect natural daylight with dental mirrors, wood spatulas, and community periodontal index probes throughout the study. Tooth surfaces were dried with gauze. The oral examinations were carried out in the selected houses and using regular chairs. No specific position was applied because beds and sofas are not available and most of the people sleep in hammocks.

Dental treatment needs included the assessment of fillings (one and two or more surfaces, crown, endodontic treatment, dental extraction, and sealants). These criteria were based on the guidelines established for the 2003 Brazilian Oral Health Survey (12). After data collection, $10 \%$ of the subjects had oral exams in order to assess intraexaminer variability.

For those subjects 15-19, 35-44, and 65-74 years of age, a simple questionnaire was applied to collect information about the estimated date (in months) of the last visit to a dentist and frequency of visits to a dentist per year; if they visited a dentist, they were requested to classify the type of service (private or public).

\section{Statistical analysis}

Mean \pm standard deviation (SD) of DMFT and dmft indexes were calculated with the help of the SPSS software package (Statistics Package for the Social Sciences, version 11.0). The chi-square test was used to verify whether the caries frequency observed was significantly different from that expected for selected variables (gender and geographic location). A significance of 5\% was set a priori.

One hundred and forty-five subjects were reexamined for the intraexaminer kappa value. These subjects were randomly selected in accordance with their age group. This procedure resulted in 15-50 subjects in each age group, which provided a representative number of $10 \%$ of the total sample. The calculation of the kappa coefficient for intraexaminer reliability for carious lesions showed values ranging from 0.68 to 1.00 . 
The kappa values for treatment needs scores were higher than 0.93 .

\section{RESULTS}

A total of 1461 individuals were examined, providing a representative sample. There were a few cases of refusals $(n=20)$. A chi-square test comparing dental caries (yes versus no) according to gender (one degree of freedom) and municipality (two degrees of freedom) showed no significant differences $(P>0.05)$.

Table 1 presents the number of individuals regarded as caries-free according to age group. The mean DMFT \pm SD and $\mathrm{dmft} \pm \mathrm{SD}$ values are presented in Table 2 , and the mean number of teeth requir-

TABLE 1. Frequency of caries-free subjects per age group on Potiguara Indian reservations, Brazil, 2007

\begin{tabular}{|c|c|c|c|c|c|}
\hline \multirow[b]{2}{*}{ Age group } & \multirow[b]{2}{*}{$n$} & \multicolumn{2}{|c|}{$\mathrm{dmft}^{\mathrm{a}}$ or $\mathrm{DMFT}^{\mathrm{b}}>0$} & \multicolumn{2}{|c|}{$\mathrm{dmft}$ or DMFT $=0$} \\
\hline & & No. & $\%$ & No. & $\%$ \\
\hline \multicolumn{6}{|l|}{ dmft index } \\
\hline $18-36$ months & 146 & 86 & 45.21 & 80 & 54.79 \\
\hline 5 years & 142 & 124 & 87.32 & 18 & 12.68 \\
\hline \multicolumn{6}{|l|}{ DMFT index } \\
\hline 12 years & 159 & 132 & 83.02 & 27 & 16.98 \\
\hline $15-19$ years & 507 & 476 & 93.89 & 31 & 6.11 \\
\hline $35-44$ years & 394 & 392 & 99.49 & 2 & 0.51 \\
\hline $65-74$ years & 113 & 112 & 99.12 & 1 & 0.88 \\
\hline Total & 1461 & 1302 & 89.20 & 159 & 10.80 \\
\hline
\end{tabular}

ing dental treatment due to caries is shown in Table 3.

Figure 1 shows the percentage distribution of DMFT scores of 12-year-old and 15- to 19-year-old children.

Considering all deciduous teeth examined ( $n=5505)$, it was observed that $21.8 \%$ were affected by caries. More specifically, the classifications for these teeth were as follows: 1106 teeth had carious lesions, 20 were properly restored, and 76 had indications for extraction. The figures for all permanent teeth examined $(n=34378)$ showed that $38.2 \%$ of these teeth were affected by caries, including teeth that were not examined because of extraction due to dental caries. The raw numbers were 5366 teeth with carious lesions, 218 teeth restored, and 7 543 teeth extracted due to caries or with indication for extraction.

With regard to the questionnaire data, of the 1014 subjects selected 21 adults did not respond to the interview. Respondents were classified in three categories: (1) subjects who reported never

TABLE 2. Mean number of sound teeth and of decayed, missing, or filled deciduous teeth and permanent teeth and components per age group on Potiguara Indian reservations, Brazil, 2007

\begin{tabular}{|c|c|c|c|c|c|c|}
\hline \multirow[b]{2}{*}{ Age group } & \multicolumn{4}{|c|}{ Tooth category } & \multirow{2}{*}{$\begin{array}{l}\text { Mean dmft } \\
\text { or } \mathrm{DMFT}^{\mathrm{b}} \\
\quad \pm \mathrm{SD}^{\mathrm{c}}\end{array}$} & \multirow{2}{*}{$\begin{array}{c}95 \% \\
\text { confidence } \\
\text { interval }\end{array}$} \\
\hline & Sound & Decayed & Missing & Filled & & \\
\hline \multicolumn{7}{|l|}{ dmft index } \\
\hline $18-36$ months & 16.66 & 2.34 & 0.07 & 0.05 & $2.53 \pm 3.76$ & $1.92-3.15$ \\
\hline 5 years & 13.22 & 5.04 & 0.46 & 0.36 & $5.87 \pm 4.31$ & $5.14-6.57$ \\
\hline \multicolumn{7}{|l|}{ DMFT index } \\
\hline 12 years & 22.58 & 2.60 & 0.38 & 0.56 & $3.68 \pm 3.18$ & $3.18-4.18$ \\
\hline 15-19 years & 21.83 & 3.47 & 1.44 & 1.94 & $7.13 \pm 4.95$ & $6.70-7.57$ \\
\hline 35-44 years & 14.35 & 3.37 & 11.81 & 1.12 & $16.43 \pm 7.56$ & 15.62-17.13 \\
\hline $65-74$ years & 6.47 & 2.94 & 19.85 & 0.06 & $22.86 \pm 8.63$ & 19.79-23.38 \\
\hline
\end{tabular}

TABLE 3. Mean number of teeth requiring treatment due to dental caries per age group on Potiguara Indian reservations, Brazil, 2007

\begin{tabular}{|c|c|c|c|c|c|c|c|c|}
\hline \multirow[b]{2}{*}{ Age group } & \multicolumn{2}{|c|}{ Fillings } & \multirow[b]{2}{*}{ Crown } & \multirow[b]{2}{*}{$\begin{array}{c}\text { Endodontic } \\
\text { treatment }\end{array}$} & \multirow[b]{2}{*}{ Extraction } & \multirow[b]{2}{*}{ Sealant } & \multirow[b]{2}{*}{$\begin{array}{c}\text { Mean } \pm \\
\text { SD }^{a}\end{array}$} & \multirow[b]{2}{*}{$\begin{array}{c}95 \% \\
\text { confidence } \\
\text { interval }\end{array}$} \\
\hline & $\begin{array}{c}\text { One } \\
\text { surface }\end{array}$ & $\begin{array}{c}\text { Two or } \\
\text { more } \\
\text { surfaces }\end{array}$ & & & & & & \\
\hline \multicolumn{9}{|l|}{ Deciduous teeth } \\
\hline $18-36$ months & 1.14 & 1.16 & 0.00 & 0.10 & 0.01 & 0.04 & $2.45 \pm 3.50$ & $1.87-3.01$ \\
\hline 5 years & 1.63 & 2.73 & 0.02 & 0.61 & 0.06 & 0.03 & $5.08 \pm 4.00$ & $4.42-5.74$ \\
\hline \multicolumn{9}{|l|}{ Permanent teeth } \\
\hline 12 years & 1.61 & 0.98 & 0.00 & 0.13 & 0.15 & 0.03 & $2.90 \pm 2.87$ & $2.45-3.35$ \\
\hline $15-19$ years & 1.88 & 1.33 & 0.01 & 0.16 & 0.40 & 0.00 & $3.78 \pm 3.64$ & $3.47-4.11$ \\
\hline $35-44$ years & 1.35 & 1.15 & 0.01 & 0.06 & 1.02 & 0.00 & $3.59 \pm 4.01$ & $3.18-3.98$ \\
\hline $65-74$ years & 0.66 & 0.43 & 0.01 & 0.00 & 2.05 & 0.00 & $3.15 \pm 3.98$ & $2.43-3.91$ \\
\hline
\end{tabular}

${ }^{a} \mathrm{SD}=$ standard deviation. 
FIGURE 1. Percentage distribution of decayed, missing, or filled permanent teeth (DMFT) scores of 12- and 15- to 19-year-old individuals on Potiguara Indian reservations, Brazil, 2007

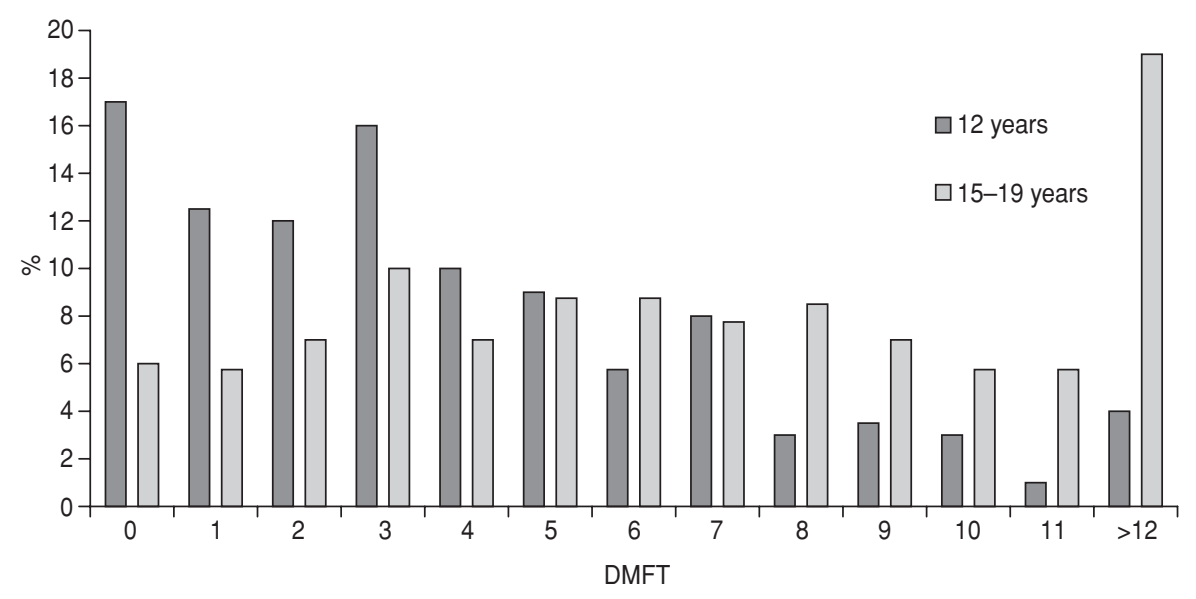

having been to a dentist ( $n=72)$, (2) subjects who visited a dentist more than one year before the date of the interview $(n=$ 462), and (3) subjects who visited a dentist within a year from the date of the interview $(n=459)$. The mean values of $\mathrm{DMFT} \pm \mathrm{SD}$ for categories 1,2 , and 3 were $7.65 \pm 8.73,14.06 \pm 9.53$, and $11.49 \pm$ 7.04, respectively. Most respondents who reported having visited a dentist stated that services were public and were located in the neighboring cities $(95 \%, n=873)$.

\section{DISCUSSION}

Unlike Amazonian Indians, who are more isolated from European culture, the Potiguara Indians in the coastal lands of Brazil have had contact with European people (Portuguese, French, and Dutch) since 1586. However, in spite of the long process of acculturation, the Potiguara still preserve cultural and dietary habits (10). The availability of processed foodstuffs was not investigated in this study but seems to play an important role in the high incidence of caries experienced by this population. In addition, the lack of oral health care instructions cannot be disregarded $(5,6)$. The absence of water fluoridation programs and low exposure to topical fluoride may contribute to the high prevalence of caries in this population. Considering the three municipalities surveyed, fluoridated drinking water is available only in the city of Baia da Traição. Hence, this anticarious beneficial effect does not reach the nearby indigenous rural areas. The drinking water in the villages of the Potiguara lands comes from lakes and wells with a very low content of fluoride (11).

According to the local Special Indigenous Health District, a regular oral health program was only recently implemented in the Potiguara lands. The low percentage of caries-free children and adults gives the dimension of the challenging caries problem. As shown in this report, there is a clear increase in caries prevalence according to age for both deciduous and permanent dentition. Actually, in the group of 65- to 74-year-olds, the mean number of carious teeth is less than in 15- to 19-year-olds and 35- to 44year-olds. However, this effect is due to the very high number of extracted teeth related to progression of the carious lesions.

The contrast in the number of permanent restored teeth compared with extracted teeth in the adult population (ratio of 1:34) suggests that dental extraction was the main, if not the only, dental procedure available for many years. This assumption is supported by the lower value of DMFT for subjects who have never been to a dentist compared with higher values for those who visit a dentist seldom or once a year. Our data support the information that regular dental treatment was not available for indigenous people in urban areas. Although no previous DMFT data are available from this population, the mean DMFT values in all age groups indicate that caries is almost ubiquitous in that population and that the widespread caries activity is not a recent event. In addition, considering the long acculturation process in the Potiguara lands, it is possible that the caries burden in the Potiguara lands took place many years earlier than in the indigenous groups of the Amazonia and central regions of Brazil (6). Unfortunately, the most recent national oral epidemiologic survey, performed in 2003, included only $1 \%$ of the Brazilian Indians (15). Thus, most Brazilian indigenous communities do not have a complete and updated oral health investigation. Nevertheless, it can be highlighted that our findings have DMFT values similar to those of the Baniwa Indians in the Tunuí-Cachoeira region in the Northwestern Amazon, Brazil, located at least 5000 kilometers from the Potiguara reservation lands. The mean $\mathrm{dmft}$ in 5year-olds in that population was 5.3, and for Potiguara children the mean was 5.8; for the 15- to 19-year-olds and for those older than 50 years the values were 8.2 and 22.1, whereas our data show 7.1 and 22.8 for similar age groups, respectively.

Our findings do not indicate that the caries prevalence in the Potiguara Indians is heading in a direction opposite that of the prevalence in urban areas of Brazil where a decline in caries can be observed $(16,17)$. First, the caries decline effect in urban areas of the Northeast Region is slower than in other parts of the country. The slower decline in caries is probably related to socioeconomic status (SES) and the availability of organized oral health programs $(17,18)$. For instance, the most updated mean DMFT for 12-year-old children in the Northeast Region is 3.2. This value is higher than 
the national mean value of 2.7. A similar difference in these values was previously observed (15).

Ten years ago, the mean DMFT of 12year-old children in nonfluoridated rural areas from Paraíba was 3.9 (18). A very similar value of 3.7 was found in the present study. Recently, it was observed that DMFT at the age of 12 years in Paraiba's urban areas is strongly related to SES. For nonfluoridated cities, the DMFT at this age is estimated to be 3.3 in public schools (low SES) and 1.3 in private schools (high SES) (19). Thus, in spite of considering the low SES of the indigenous 12-year-old children, their DMFT is slightly higher than that in the urban areas of Paraíba.

Most 12-year-old Potiguara children have a DMFT of 3.0, whereas for the 15to 19-year-old age group the most frequent DMFT values observed were higher than 12.0. These data clearly indicate that caries activity speeds up among adolescents. Because caries incidence does not level off easily with time, future cohort studies are warranted in order to present the real trend in caries increments between these two age groups.

The amount of treatment needs is very high. Actually, the large amount of dental treatment demanded in these areas supports the evidence that the World Health Organization goals for the year 2000 were not achieved regardless of the age group. Because dental caries can be connected to other variables, an oral health program based on social and health inequalities must be implemented. Culture habits must be protected, but oral hygiene instructions can be introduced under careful guidance in order to increase the value of a good oral health program.

Overall, the present study shows that indigenous children and adults living in Potiguara lands have higher levels of dental caries than their nonindigenous counterparts. Unfortunately, no scientifically validated data on dietary habits are available for this population. The cultural differences between rural and urban communities will be reduced in the near future when new roads and new links will be established. To date, there is no doubt that cariogenic foodstuffs (sugar, candies, soft drinks) can be purchased by the Potiguara Indians. The magnitude of this variable for caries development among Potiguara people is still a matter of investigation. Finally, there is clear evidence that high caries activity is taking place, resulting in many unrestored teeth, endodontic treatment, and extractions in all age groups examined.

Acknowledgments. The authors thank the Conselho Nacional de Desenvolvimento Científico e Tecnológico (CNPq) and Fundação de Apoio à Pesquisa do Estado da Paraíba (FAPESQ) for financial support. We are also grateful to the Brazilian National Health Foundation (FUNASA) and all Indians living on the Potiguara reservations for their willingness to cooperate with the study.

\section{REFERENCES}

1. Neel JV, Salzano FM, Junqueira PC, Keiter F, Maybury-Lewis D. Studies on the Xavante Indians of the Brazilian Mato Grosso. Am J Hum Genet. 1964;16:52-140.

2. Niswander JD. Further studies on the Xavante Indians. VII. The oral status of the Xavantes of Simões Lopes. Am J Hum Genet. 1967;19:543-53.

3. Tumang AJ, Piedade EF. Cárie dental, doenças peridontais e higiene oral em indígenas brasileiros. Bol Oficina Sanit Panam. 1968;64:103-9.

4. Donnelly CJ, Thomson LA, Stiles HM, Brewer C, Neel JV, Brunelle JA. Plaque, caries, periodontal diseases, and acculturation among Yanomami Indians, Venezuela. Community Dent Oral Epidemiol. 1977;5:30-9.

5. Rigonatto DDL, Antunes JLP, Frazão P. Dental caries experience in Indians of the Upper Xingu, Brazil. Rev Inst Med Trop Sao Paulo. 2001;43:93-8.

6. Carneiro MCG, Santos RV, Garnelo L, Rebelo MAB, Coimbra CEA Jr. Cárie dentária e necessidade de tratamento odontológico entre os índios Baniwa do Alto Rio Negro, Amazonas. Ciên Saúde Colet. 2008;13: 1985-92.

7. Salzano FM. Parasitic load in South American tribal populations. In: Swedlund AC, Armelagos GJ, eds. Disease in populations in transition: anthropological and epidemiological perspectives. New York: Bergin and Garvey; 1990. Pp. 201-21.
8. Lyon P. Native South American: ethnology of the least known continent. Boston: Little and Brown; 1974.

9. Instituto de Pesquisa Econômica Aplicada, Programa das Nações Unidas para o Desenvolvimento (PNUD), Fundação João Pinheiro. Atlas do desenvolvimento humano no Brasil. Brasília: Instituto de Pesquisa Econômica Aplicada; 2007.

10. Vieira JG. Somos índios misturados: o sangue, a terra e a concepção de tempo e de espaço dos Potiguara da Paraíba. Raízes. 2002;21:81-90.

11. Sampaio FC, von der Fehr FR, Arneberg P, Gigante DP, Hatløy A. Dental fluorosis and nutritional status of 6- to 11-year-old children living in rural areas of Paraíba, Brazil. Caries Res. 1999;33:66-73.

12. Brasil, Ministério da Saúde. Projeto SB2000: Condições de Saúde Bucal da população brasileira no ano 2000: manual do coordenador. Brasília: Ministério da Saúde; 2001. Série C; Projetos, Programas e Relatórios 51. Available from: http://bvsms.saude.gov.br/ bvs/publicacoes/condSB_man_coord.pdf. Accessed 10 March 2009.

13. Lwanga SK, Lemeshow S. Sample size determination in health studies. A practical manual. Geneva: World Health Organization; 1991.

14. World Health Organization. Oral health surveys: basic methods. 4th ed. Geneva: WHO; 1997.
15. Brasil, Ministério da Saúde, Secretaria de Atenção à Saúde, Departamento de Atenção Básica, Coordenação Nacional de Saúde Bucal. Projeto SB BRASIL 2003: condições de saúde bucal da população brasileira 20022003. Resultados principais. Brasília: Ministério da Saúde; 2004.

16. Narvai PC, Frazão P, Roncalli AG, Antunes JL. Dental caries in Brazil: decline, polarization, inequality and social exclusion. Rev Panam Salud Publica. 2006;19(6):385-93.

17. Souza ML, Bastos JL, Peres MA. Trends in dental caries rates in 12- and 13-year-old schoolchildren from Florianópolis (Brazil) between 1971 and 2005. Oral Health Prev Dent. 2006;4:187-92.

18. Sampaio FC, Hossain AN, von der Fehr FR, Arneberg P. Dental caries and sugar intake of children from rural areas with different water fluoride levels in Paraíba, Brazil. Community Dent Oral Epidemiol. 2000;28(4):307-13.

19. Moreira PV, Rosenblatt A, Passos IA. Prevalence of cavities among adolescents in public and private schools in João Pessoa, Paraíba State, Brazil. 1: Ciên Saúde Colet. 2007;12: 1229-36.

Manuscript received on 17 May 2009. Revised version accepted for publication on 20 September 2009. 
RESUMEN Objetivo. El objetivo de este estudio fue evaluar la prevalencia de caries y las necesidades de tratamiento en los residentes indígenas brasileños de una reserva india.

Métodos. En este estudio transversal se incluyó a 1461 personas de 18 a 36 meses de

Caries dental y necesidades de tratamiento en los indígenas de la reserva india Potiguara de Brasil edad, y de 5, 12, 15-19, 35-44, y 65-74 años, que vivían en aldeas indias Potiguara de Brasil. Se determinaron los dientes permanentes cariados, perdidos y obturados (CPO) y los dientes deciduos mediante examinadores calibrados, con ayuda del método recomendado por la Organización Mundial de la Salud. Las necesidades de tratamiento se evaluaron con las directrices de la Encuesta Brasileña de Salud Bucodental de 2003.

Resultados. Las medias \pm desviaciones estándar (DE) de los dientes deciduos de los niños de 18 a 36 meses, y de cinco años fueron $2,5 \pm 3,7$ y 5,8 \pm 4,3, respectivamente. En los grupos de edad de 12, 15-19, 35-44, y 65-74 años, los valores de la media \pm DE de los dientes CPO fueron 3,6 $\pm 3,1,7,1 \pm 4,9,16,4 \pm 7,5$, y 22,8 \pm 8,6. La media $\pm \mathrm{DE}$ del número de dientes deciduos que precisaron tratamiento varió de 2,4 $\pm 3,5$ a 5,0 \pm 4,0 en los grupos de edad de 18 a 36 meses, y 5 años, respectivamente. En los adolescentes y adultos, se observó que, en promedio, por lo menos tres dientes permanentes precisaron tratamiento dental en forma de obturaciones, coronas, endodoncia y extracciones.

Conclusiones. En todos los grupos de edad de los indios Potiguara se observaron una prevalencia alta de caries y muchos dientes que precisaban tratamiento.

Palabras clave Caries dental; índice CPO; encuestas de salud bucal; servicios de salud dental; población indígena; Brasil. 